\title{
Próba rekonstrukcji pierwotnej rzeźby obszaru Zespołu Staromiejskiego w Toruniu i jego bliskich przedmieść na podstawie geoinformacji geologicznej $i$ historycznej
}

\author{
An attempt to reconstruct the primary relief of the Old Town of Torun and its close \\ suburbs on the basis of the geological and historical geoinformation
}

\author{
Paweł Molewski, Włodzimierz Juśkiewicz \\ Katedra Geomorfologii i Paleogeografii Czwartorzędu, Uniwersytet Mikołaja Kopernika, Toruń, molewski@umk.pl
}

Zarys treści: Autorzy przedstawiają źródła, metody i wyniki analiz przestrzennych, których celem było odtworzenie pierwotnej rzeźby obszaru Zespołu Staromiejskiego w Toruniu i jego bliskich przedmieść. Badania oparte zostały na danych geologicznych, archeologicznych i historycznych. Dane te zebrano i przetransformowano do postaci umożliwiającej wspólną analizę na platformie GIS. Końcowym rezultatem badań jest próba rekonstrukcji rzeźby analizowanego obszaru sprzed lokacji miasta (XIII w.) i jej późniejszych przekształceń, głównie antropogenicznych. Zmiany te zostały scharakteryzowane ilościowo, a pierwotne ukształtowanie rozpatrywanego terenu zwizualizowano w postaci modelu rzeźby.

Słowa kluczowe: rekonstrukcja pierwotnej rzeźby terenu, geoinformacja geologiczna, geoinformacja historyczna, Zespół Staromiejski w Toruniu

\begin{abstract}
The authors present the sources, methods and results of the spatial analyses, the aim of which was to recreate the original relief of the area of the Old Town of Torun and its close suburbs. The researches were based on the geological, archaeological and historical data. These data were collected and transformed into the form which permits their joint analysis in the GIS. The outcome of the study is an attempt to reconstruct the relief of the analysed area before the foundation of the town $\left(13^{\text {th }} \mathrm{c}\right.$.) and its subsequent transformations, mainly anthropogenic. These changes were characterised quantitatively, and the original relief of the area in question was visualised as a relief model.
\end{abstract}

Key words: reconstruction of the original relief, geological geoinformation, historical geoinformation, Old Town of Toruń

\section{Wstęp}

Zespół Staromiejski w Toruniu obejmujący w części zachodniej Stare Miasto, a wschodniej Nowe Miasto, obydwa lokowane w XIII w. - i jego bliskie przedmieścia położone są w Kotlinie Toruńskiej (Kondracki 1998), na prawym brzegu Wisły. Współczesna rzeźba tego terenu przekształcona antropogenicznie była kilkakrotnie opisywana w ramach opracowań dotyczących większych obszarów (m.in. Galon 1961, Niewiarowski, Tomczak 1969, 1973, Tomczak 1971, 1999, Niewiarowski, Weckwerth 2006). Analizowany teren obejmuje niewielkie fragmenty dwóch teras pradolinnych i dwóch rzecznych oraz równinę zalewową Wisły (ryc. 1A). Powierzchnię teras, rozdzielonych złagodzonymi krawędziami, urozmaicają nieliczne zachowane wzniesienia wydmowe, a równinę zalewową - starorzecza. W rzeźbie teras dominują równie niwelacyjne powstałe $\mathrm{w}$ wyniku wyrównania terenu lub tworzenia nasypów powierzchniowych. Charakterystycznymi formami rzeźby antropogenicznej są pozostałości fortyfikacji miasta. Rozpatrywany obszar charakteryzuje się znacznym zróżnicowaniem hipsometrycznym (ryc. 1B). Jego najniżej położona część znajduje się na równinie zalewowej Wisły (34 m n.p.m.), najwyższa zaś na wschód od Zespołu Staromiejskiego na terasie pradolinnej (70 m n.p.m.). Maksymalna różnica wysokości 

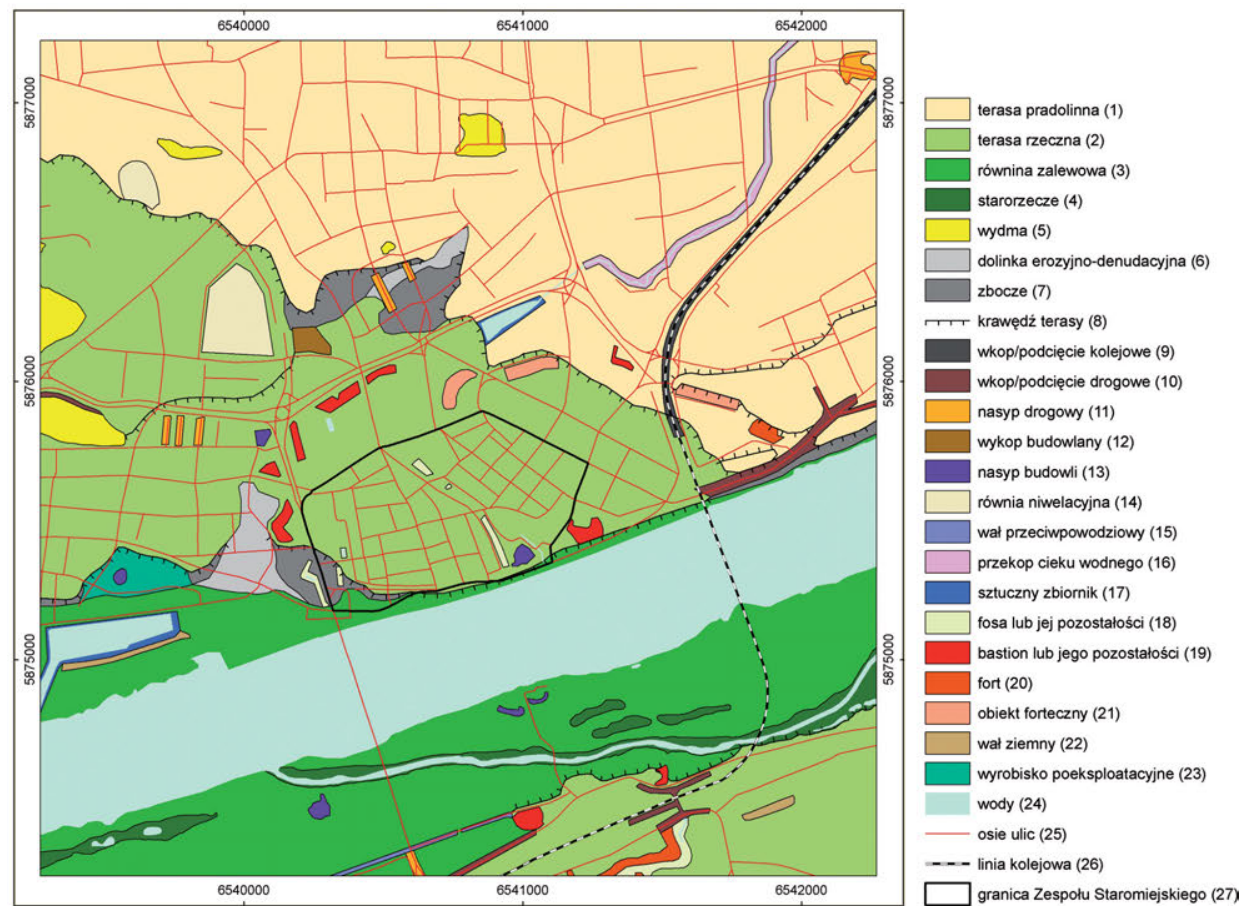

A $\quad 0.250, \quad 500,1000 \mathrm{~m}$
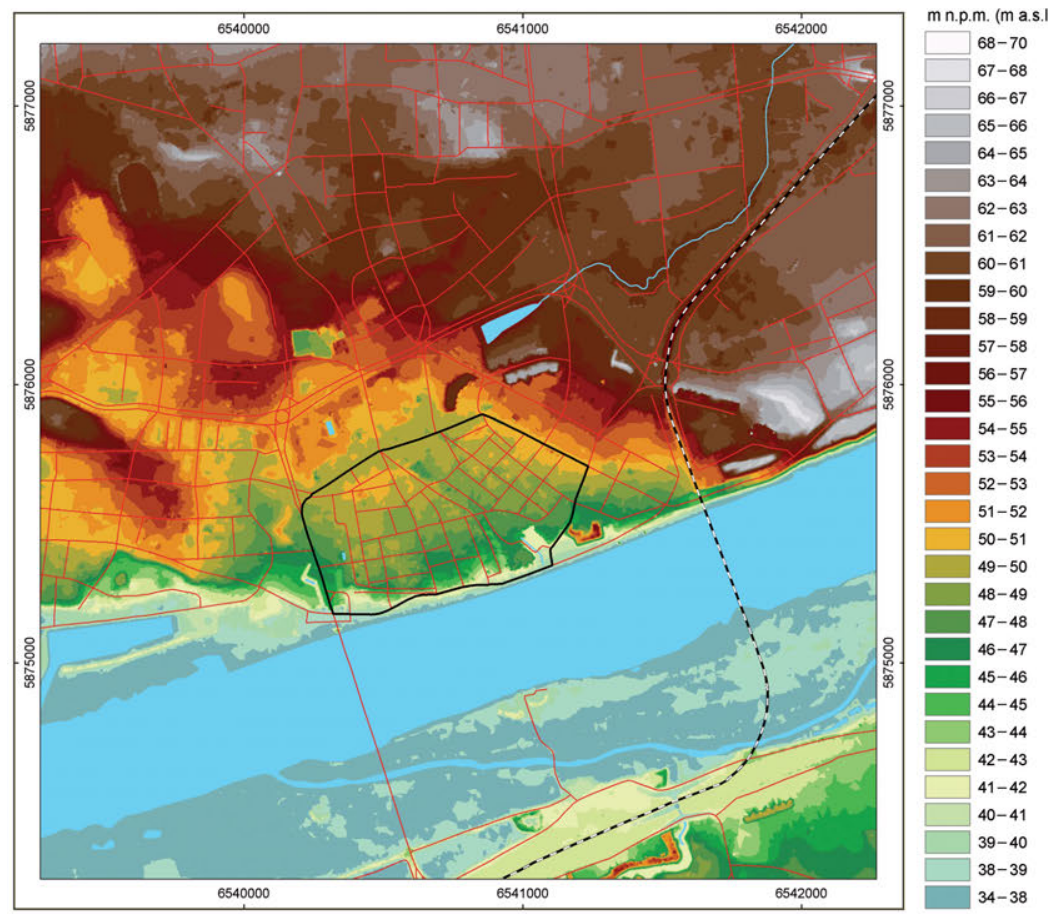

B

$1000 \mathrm{~m}$

Ryc. 1. A - mapa geomorfologiczna obszaru Zespołu Staromiejskiego w Toruniu i jego bliskich przedmieść; B - cyfrowy model wysokościowy Zespołu Staromiejskiego w Toruniu i jego bliskich przedmieść

1 - wody, 2 - osie ulic, 3 - linia kolejowa, 4 - granica Zespołu Staromiejskiego w Toruniu

Fig. 1. A - geomorphology of the Old Town of Torun and its close suburbs

1 - ice-marginal valley terrace, 2 - river terrace, 3 - floodplain, 4 - oxbow, 5 - dune, 6 - erosion-denudational valley, 7 - slope, 8 - escarpment of a terrace; convex and concave anthropogenic forms evident in the scale and resolution of the digital elevation model: 9 - railway trench/undercut, 10 - road trench/undercut, 11 - road embankment, 12 - construction trench, 13 - construction embankment, 14 - levelling plane, 15 - flood embankment, 16 crosscut watercourse, 17 - artificial reservoir, 18 - moat or its remains, 19 - bastion or its remains, 20 - fort, 21 - fortress object, 22 - earth embankment, 23 - disused excavation pit, 24 - waters, 25 - streets' axes, 26 - railway line, 27 - boundary of the Old Town of Torun

$\mathrm{B}$ - digital elevation model of the Old Town of Torun and its close suburbs

1 - waters, 2 - streets' axes, 3 - railway line, 4 - boundary of the Old Town of Toruń 
bezwzględnych na analizowanym obszarze wynosi więc około $36 \mathrm{~m}$. Największe wysokości względne występują w obrębie zboczy teras $(8-30 \mathrm{~m})$ i wydm $(11 \mathrm{~m})$.

Istniejące prace zawierające ogólne dane dotyczące antropogenicznych przekształceń rzeźby rozpatrywanego terenu mają szerszy zakres tematyczny lub obszarowy (Niewiarowski, Tomczak 1969, 1973, Fedorowicz 1993, Podgórski 1996, 2005, Tomczak 1999, Niewiarowski, Weckwerth 2006). Zawarte w nich opisy zmian rzeźby mają charakter niemal wyłącznie jakościowy. Jedynie północno-wschodni fragment badanego terenu, obejmujący południową część dzielnicy Mokre, był szczegółowo analizowany m.in. pod względem zmian ilościowych rzeźby (Molewski 1995, 2011).

Celem przeprowadzonych badań było odtworzenie pierwotnej, tj. sprzed lokacji miasta, rzeźby terenu o powierzchni 7,67 km², obejmującego Zespół Staromiejski w Toruniu (pow. 0,49 $\mathrm{km}^{2}$ ) i jego bliskie przedmieścia na podstawie danych geologicznych, archeologicznych i historycznych. Dane te zebrano i przetransformowano do postaci umożliwiającej wspólną analizę na platformie GIS. Analiza przestrzenna pozwoliła m.in. na oszacowanie zmian rzeźby tego obszaru od XIII w. oraz stworzenie modelu jego pierwotnego ukształtowania.

\section{Materiały źródłowe i metody badań}

Cel badań realizowany był w kilku odrębnych zadaniach, których wyniki były następnie integrowane i analizowane w oprogramowaniu GIS. Opracowano rastrowy, cyfrowy model wysokościowy (CMW) współczesnej rzeźby analizowanego terenu w układzie współrzędnych 2000 (ryc. 1B). Model wykonano na podstawie 213865 punktów wysokościowych, tj. punktów pomiarów geodezyjnych pozyskanych z urzędów państwowych i punktów z modelu fotogrametrycznego (CODGiK). Model ten stanowi dokładny, ciągły obraz współczesnego ukształtowania analizowanej powierzchni.

Zebrano i zarchiwizowano w cyfrowej bazie danych informacje o powierzchniowej budowie geologicznej badanego terenu (ryc. 2). Źródłem danych geologicznych były głównie wiercenia geologiczno-inżynierskie (80,9\%), w mniejszym stopniu wiercenia hydrogeologiczne $(9,4 \%)$ oraz wykopy archeologiczne (9,7\%). Profile wierceń uzyskano z urzędów i instytucji państwowych, zaś dane z wykopów archeologicznych z bazy stanowisk archeologicznych opracowanej w Instytucie Archeologii UMK w Toruniu. Zarchiwizowano 1076 wierceń i 104 wykopy archeologiczne. $Z$ opisów profili wierceń pozyskano informacje o litologii (w tym miąższości gruntów nasypowych) i stratygrafii podłoża geologicznego oraz głębokości zalegania pierwszego poziomu wód gruntowych. Z wykopów archeologicznych uzyskano dane o głębokości zalegania calca (powierzchni naturalnej nie zawierającej materiału kulturowego), a tym samym o łącznej miąższości warstw kulturowych i nowożytnych gruntów nasypowych (w dalszej części artykułu określanych łącznie jako nasyp po-

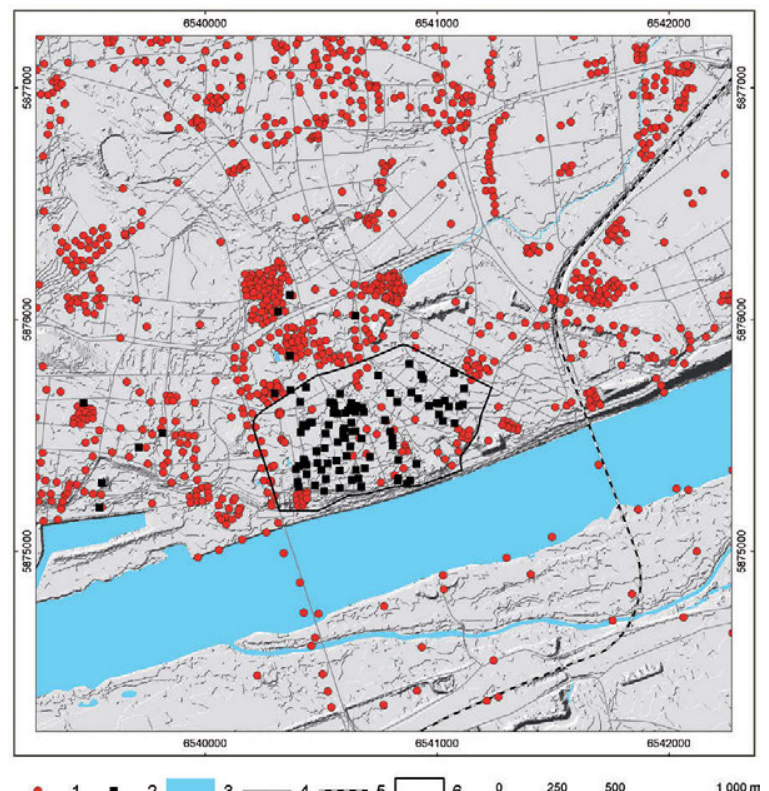

Ryc. 2. Mapa rozmieszczenia wierceń geologiczno-inżynierskich i hydrogeologicznych oraz wykopów archeologicznych 1 - wiercenia, 2 - wykopy, 3 - wody, 4 - osie ulic, 5 - linia kolejowa, 6 - granica Zespołu Staromiejskiego w Toruniu

Fig. 2. Distribution of geological-engineering and hydrogeological drillings as well archaeological excavations

1 - drillings, 2 - excavations, 3 - waters, 4 - streets' axes, 5 - railway line, 6 - boundary of the Old Town of Torun

wierzchniowy albo nasyp). Istotnym ograniczeniem prowadzonych analiz było nierównomierne rozmieszczenie wierceń. Wiercenia geologiczno-inżynierskie, ze względu na ich zadanie, rozlokowane są w postaci skupień lub linii, w zależności od charakteru planowanych prac inwestycyjnych. Na rozmieszczenie wierceń wpływa również charakter użytkowania i stopień zagospodarowania terenu. Ponadto $w$ bazie nie umieszczono części wierceń $z$ uwagi na zły stan zachowania i czytelność materiałów archiwalnych. Wykopy archeologiczne koncentrują się na obszarze Zespołu Staromiejskiego, uzupełniając istotną lukę w rozmieszczeniu wierceń.

Dokonano kwerendy istniejących historycznych planów i map Torunia. Szczególnie przydatne okazały się plany i mapy z przełomu XVIII i XIX w. przedstawiające jeszcze obraz miasta feudalnego, nie zmienionego od średniowiecza. W oparciu o współczesny plan geodezyjny miasta dokonano georeferencji i kalibracji wybranych planów i map historycznych. Podstawowym kryterium ich doboru były: kartometryczność, skala, czytelność rysunku $\mathrm{i}$ istnienie odwzorowania rzeźby. Najstarszym w przybliżeniu kartometrycznym planem, przydatnym dla prowadzonych analiz, był rękopiśmienny plan miasta z 1793 r., tzw. plan Douglasa, w skali około 1:5600 (ryc. 3A). W analizie wykorzystano również m.in.: rękopiśmienny pruski plan fortyfikacji Torunia z 1837 r. w skali około 1:12 250 (ryc. 3B), powstały prawdopodobnie według założeń realizacji map arkuszowych w skali 1:25 000, tzw. Urmesstischblätt (Jankowska 1993); drukowaną niemiecką mapę w skali 1:25 000 z 1909 r., tzw. Messtischblätt (ryc. 3C) i rękopiśmienny plan Torunia w skali 1:10 000 wykonany w latach 


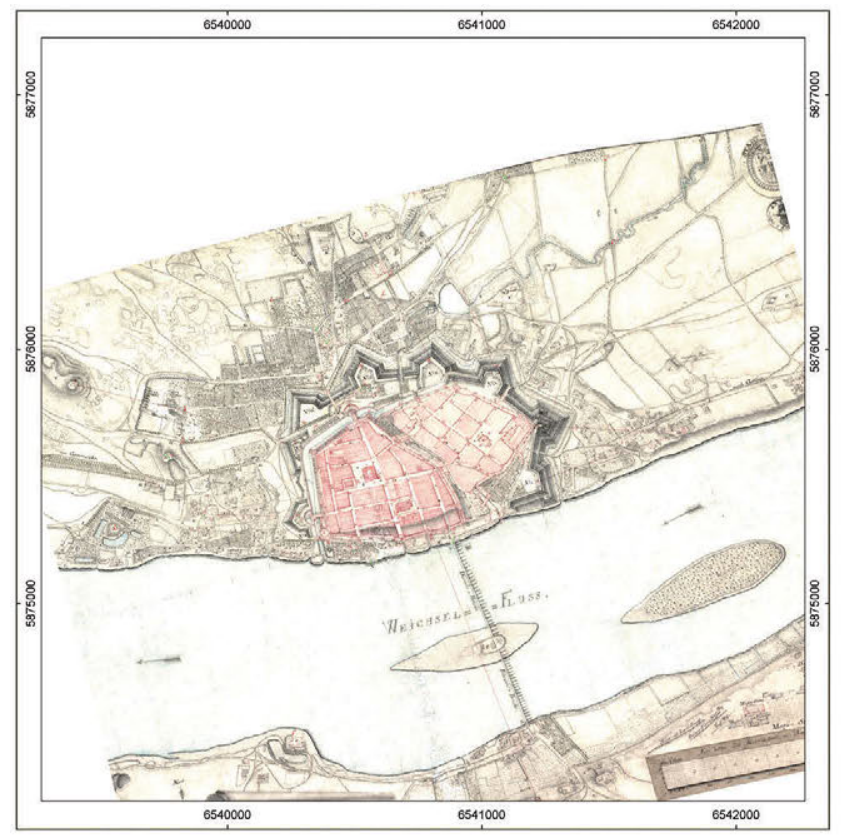

A

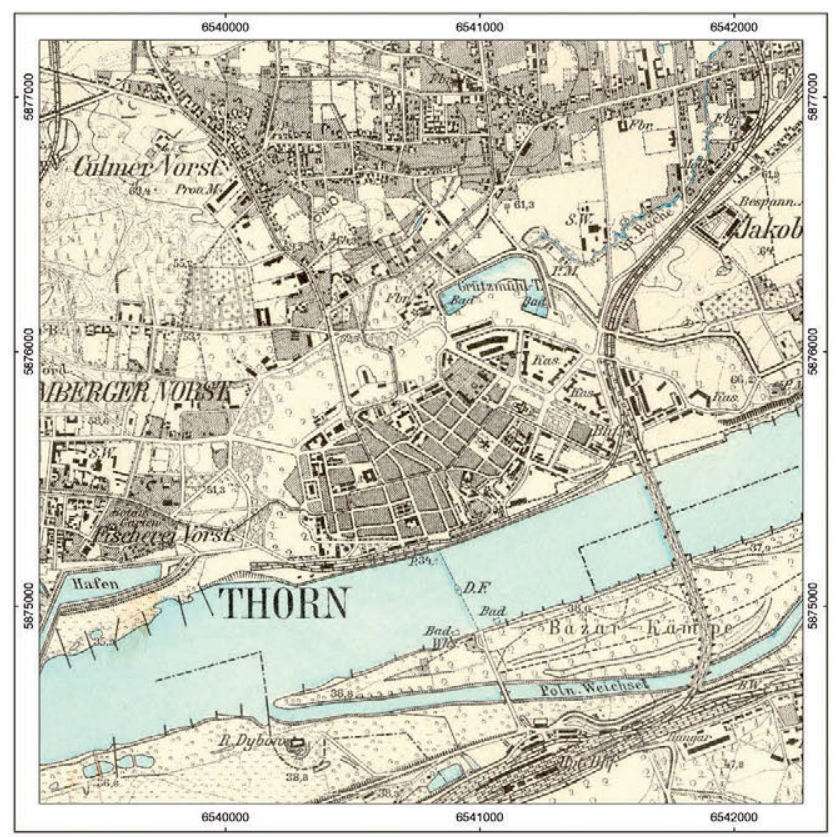

C

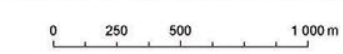

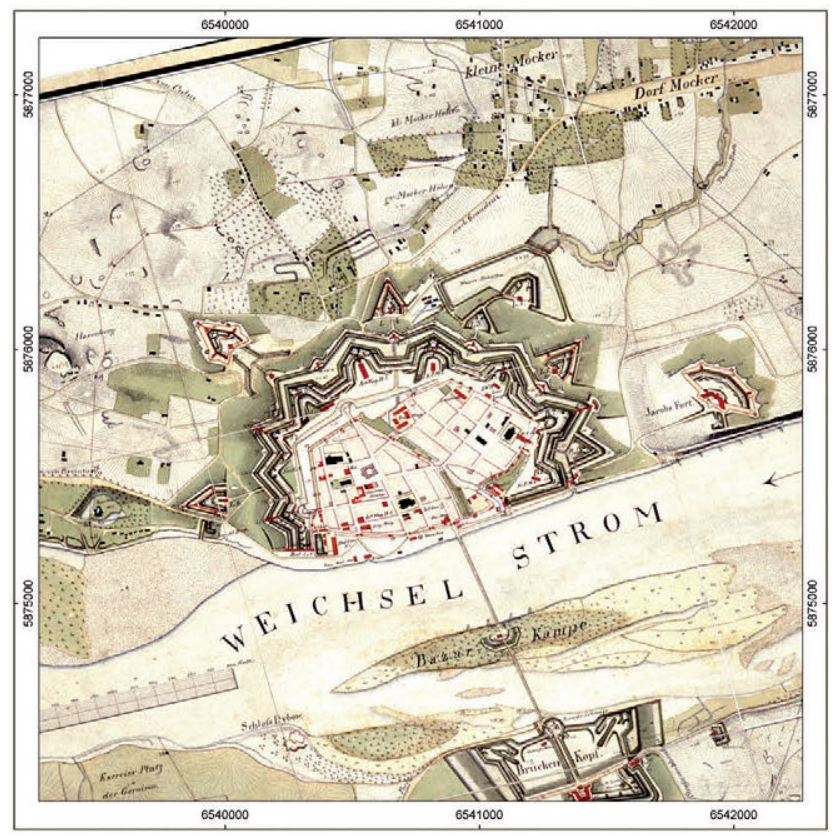

B $\quad 2^{250},{ }^{500}, \ldots,{ }^{1000}$

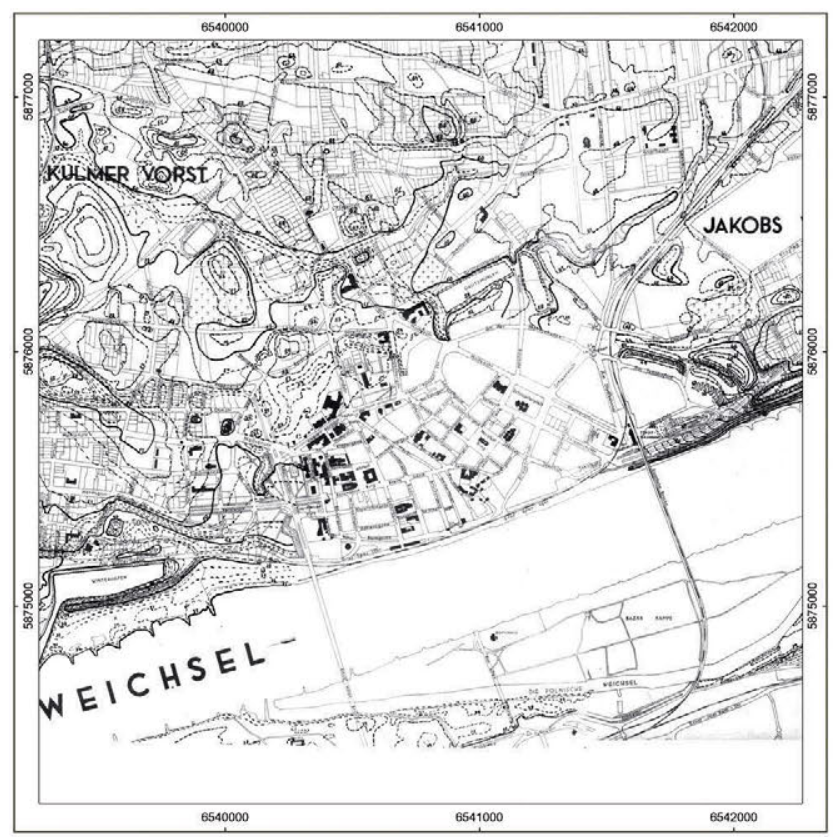

D $\quad 2 .{ }^{250},{ }^{500},{ }^{1000 m}$

Ryc. 3. Przykłady rektyfikowanych, wybranych do analiz planów i map historycznych

A - Specialer Plan Der Königlisch West-Preussischen an der Weichsel liegenden Handlungs Stadt und Festung Thorn, nebst ihrer umliegenden Gegend aufgenommen im Jahre 1793, B - Plan der Befestigung von Thorn im Jahre 1837, C - Topographische Karte 1:25 000 (Messtischblätt), Thorn 1909, D - rękopiśmienny plan Torunia z okresu II wojny światowej (1:10 000)

Fig. 3. Examples of rectified historical maps and plans selected for the analyses

A - Specialer Plan Der Königlisch West-Preussischen an der Weichsel liegenden Handlungs Stadt und Festung Thorn, nebst ihrer umliegenden Gegend aufgenommen im Jahre 1793, B - Plan der Befestigung von Thorn im Jahre 1837, C - Topographische Karte 1:25 000 (Messtischblätt), Thorn 1909, D - manuscript of the Torun city plan from World War II (1:10 000)

II wojny światowej (ryc. 3D). Możliwość wykorzystania również XX-wiecznych materiałów kartograficznych w rekonstrukcji rzeźby przedmieść Zespołu Staromiejskiego w Toruniu wynika ze specyfiki rozwoju przestrzennego miasta (Kwiatkowska 1973). W twierdzy, jaką był Toruń w zaborze pruskim, inwestycje na przedmieściach były bardzo ograniczone, a znaczne tereny bliskich przedmieść zachowały swój prawie naturalny charakter do połowy XX w. Pozyskane materiały kartograficzne pochodzą ze zbiorów Archiwum Państwowego w Toruniu i Archiwum Map Zachodniej Polski (mapy.amzp.pl). 
Zastosowana procedura badawcza mająca na celu rekonstrukcję pierwotnej rzeźby analizowanego terenu obejmowała kolejne etapy:

1. Analiza historycznych planów i map Torunia oraz źródeł tekstowych pod kątem informacji o pierwotnej rzeźbie terenu i jej przekształceniach.

2. Inwentaryzacja i oznaczenie na rastrowym, cyfrowym modelu wysokościowym współczesnego ukształtowania terenu form rzeźby lub ich części, które zostały przekształcone, uległy niwelacji lub zostały przykryte nasypami powierzchniowymi.

3. Oszacowanie miąższości nasypów powierzchniowych na badanym terenie w oparciu o analizę geostatystyczną danych geologicznych i archeologicznych.

4. Wygenerowanie rastrowego, cyfrowego modelu wysokościowego badanego terenu po zdjęciu nasypów powierzchniowych w oparciu o algebrę rastrową.

5. Rekonstrukcja pierwotnego ukształtowania analizowanego terenu poprzez modyfikację punktów wysokościowych modelu na podstawie planów i map historycznych, tj. dodanie współcześnie nieistniejących, zniwelowanych naturalnych form rzeźby lub ich części i eliminację odwzorowanych na modelu form antropogenicznych. Na podstawie najstarszych materiałów kartograficznych i widoków miasta (Biskup red. 1998) przybliżone uzupełnienie rekonstrukcji formami nie mającymi odwzorowania morfometrycznego rysunkiem poziomicowym lub punktami wysokościowymi.

6. Na podstawie cyfrowych modeli wysokościowych współczesnej i pierwotnej, zrekonstruowanej powierzchni dokonanie szacunkowego bilansu rzeźby rozpatrywanego terenu w oparciu o algebrę rastrową. Przyjęta procedura badawcza obciążona jest wieloma ograniczeniami:

- brakiem informacji geologicznej o części analizowanego terenu, w tym miąższości nasypów powierzchniowych;

- niemożnością określenia relacji pierwotnego ukształtowania terenu do powierzchni kopalnej odsłaniającej się po zdjęciu nasypów;

- niewystarczającą ilością i szczegółowością informacji dotyczących pierwotnego ukształtowania terenu, pochodzących ze źródeł, w tym planów i map historycznych;

- w przypadku najstarszych materiałów kartograficznych zastosowaniem metody kreskowej dla odzwierciedlenia rzeźby i brakiem możliwości określenia wysokości terenu.

\section{Przeobreżania rzeźby analizowanego terenu}

Jak już wspomniano, rzeźba analizowanego obszaru jest przekształcona antropogenicznie. Najstarsze z tych przekształceń powstały prawdopodobnie $\mathrm{W}$ miejscu wzniesionego w XIII-XIV w. zamku krzyżackiego położonego nad brzegiem Wisły między Starym i Nowym Miastem. Miejsce to było zasiedlane już od końca epoki brązu (Chudziakowa 1963). Głównie w efekcie procesów antropogenicznych złagodzone zostały krawędzie teras i prawdopodobnie zanikły niewielkie obniżenia dolinne rozcinające ich zbocza. Zniwelowane lub przekształcone zostały wydmy, pierwotnie występujące głównie w północnej i zachodniej części bliskich przedmieść Zespołu Staromiejskiego. Istotne zmiany zaszły na równinie zalewowej Wisły. We współczesnej rzeźbie przeważają wyróżnione przez Galona (1979) tzw. „,bezpośrednie formy antropogeniczne" będące skutkiem wyłącznie działalności człowieka. Uchwycenie wyodrębnionych przez tego autora ,pośrednich form antropogenicznych”, będących efektem naturalnych procesów morfogenetycznych wywołanych antropopresją, jest ograniczone. W ogólnej charakterystyce zmian antropogenicznych rzeźby na rozpatrywanym terenie oparto się na klasyfikacji antropogenicznych form rzeźby terenu i terminologii zastosowanej przez Podgórskiego (1996).

Pod względem powierzchni dominującymi antropogenicznymi formami rzeźby są ukształtowane w wyni$\mathrm{ku}$ osadnictwa równie niwelacyjne terenów zabudowy mieszkaniowej i obiektów użyteczności publicznej. Powstały one w wyniku niwelacji lub tworzenia nasypów powierzchniowych. Na mapie geomorfologicznej (ryc. 1A) zaznaczono jedynie przykłady takich równi wyraźnie wyodrębniających się na modelu wysokościowym (ryc. 1B), tj. stadion i cmentarz w północno-zachodniej części analizowanego terenu.

Istotnymi elementami rzeźby antropogenicznej są formy związane z komunikacją. Na badanym obszarze przebiega sieć ulic i linia kolejowa wraz z częścią infrastruktury stacji kolejowej Toruń Główny, położonej na lewym brzegu Wisły. Największe zagęszczenie ulic występuje na terenie Zespołu Staromiejskiego. Elementami rzeźby antropogenicznej związanej z komunikacją obok równi niwelacyjnych są formy liniowe: nasypy/wkopy drogowe i kolejowe, podcięcia dróg i rowy odwodnieniowe związane z siecią drożną. Ze względu na niewielką wysokość i szerokość tych form większość nie została odwzorowana na CMW. Najbardziej czytelnym elementem tej rzeźby jest głęboki wykop linii kolejowej pokonującej znaczną różnicę wysokości między terasami we wschodniej części analizowanego terenu (ryc. 1).

Charakterystycznymi formami rzeźby antropogenicznej Torunia są pozostałości fortyfikacji miasta. Należą do nich ślady fos istniejących już w końcu XIII w. (Fedorowicz 1993), a zasypanych w drugiej połowie XIX w. (Tomczak 1999), pozostałości XVIII- i XIX-wiecznych bastionów ziemnych oraz wkomponowane w naturalne formy rzeźby, tj. zbocza teras i wydm, przykryte nasypami ziemnymi budowle pruskich fortyfikacji (Podgórski, Chechłowska 2011).

Za częściowo „pośrednie formy antropogeniczne” rzeźby można uznać zmiany, jakie zaszły w zasięgu i ukształtowaniu równiny zalewowej Wisły. Zmiany te zachodziły w sposób naturalny niemal do drugiej połowy XIX w., kiedy przystapiono do regulacji Wisły na odcinku toruńskim. W rezultacie szerokość Wisły na wysokości 


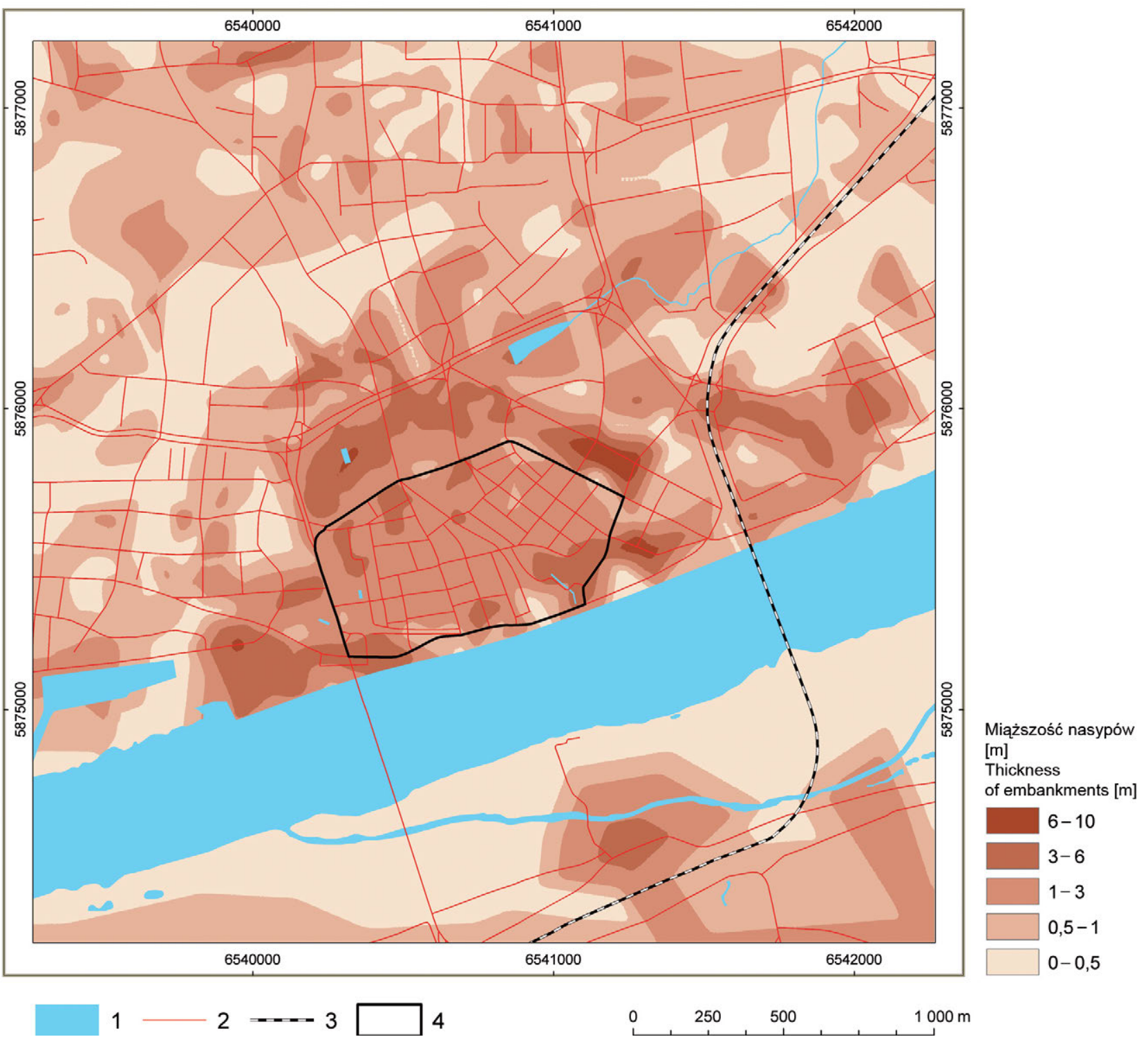

Ryc. 4. Numeryczny model miąższości nasypów

Fig. 4. Numerical model of the thickness of the embankments

Zespołu Staromiejskiego zmniejszyła się o połowę w porównaniu z końcem XVIII w. (por. ryc. 1, 3A). Nadbudowane dwie kępy rzeczne, Bazarowa i Zielona, ta pierwsza położona naprzeciw Zespołu Staromiejskiego, zostały niemalże przyłączone do brzegu rzeki (współcześnie oddziela je od brzegu starorzecze, tzw. Mała Wisełka o szerokości 20-25 m). Przypuszcza się, że do końca XVIII w. Wisła była stosunkowo stabilna, a zasięg jej koryta nie różnił się w istotny sposób od tego ze schyłku wczesnego średniowiecza (Tomczak 1971).

Spośród elementów rzeźby związanych z bezpośrednią działalnością człowieka, istotnych dla rekonstrukcji, należy wymienić wały przeciwpowodziowe pochodzące z przełomu XIX i XX w. (Fedorowicz 1993), których fragment usytuowany jest $\mathrm{w}$ skrajnie południowej części analizowanego terenu. W końcu XIX w. powstał na zachód od Zespołu Staromiejskiego, na nadbudowanej równinie zalewowej z wykorzystaniem starorzeczy, tzw. Port Zimowy. Znajduje się on poza obszarem rekon- struowanej powierzchni, co wynika ze wspomnianego znacznie większego zasięgu koryta rzeki do końca XVIII w. Spośród innych elementów rzeźby związanych z siecią hydrograficzną należy wymienić przekop Strugi Toruńskiej. Mimo że znany jest generalny przebieg naturalnych cieków analizowanego terenu, odtworzenie uformowanych przez nie form dolinnych jest ze względu na przekształcenia antropogeniczne praktycznie niemożliwe. Struga oraz naturalne cieki w obrębie Zespołu Staromiejskiego i jego bliskich przedmieść były wykorzystywane gospodarczo (np. młyny wodne) lub do napełniania fos. Jednym $z$ zachowanych i czytelnych na CMW elementów rzeźby, związanych z gospodarczym wykorzystaniem Strugi Toruńskiej, jest wielokrotnie przebudowywany staw młyński, tzw. Kaszownik, położony na północny wschód od Zespołu Staromiejskiego. Pierwotna misa stawu była prawdopodobnie jednym z wyrobisk znajdującej się tu jeszcze w XVIII w. cegielni (Tomczak 1999). 
a
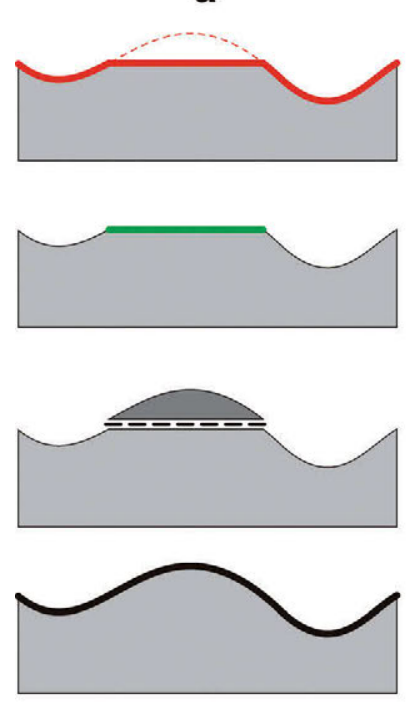

b
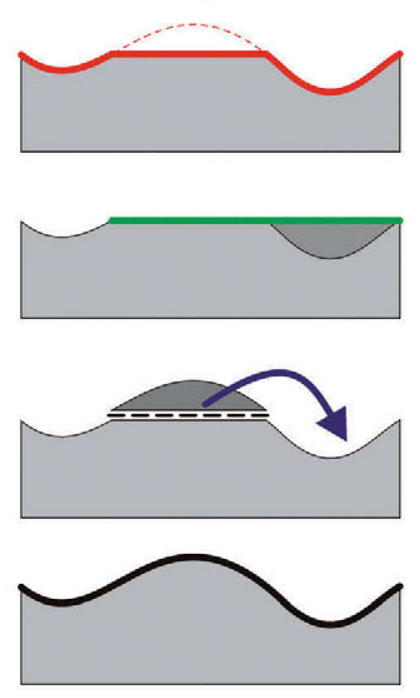
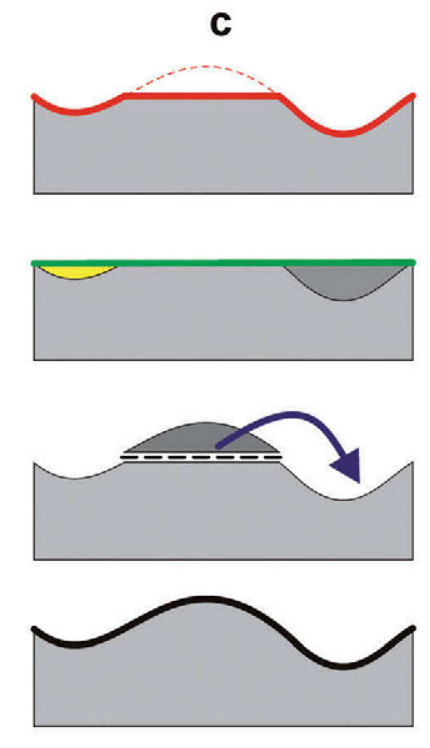

5 d
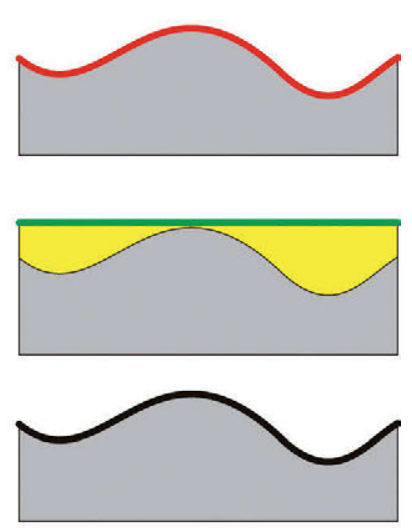

6

Ryc. 5. Relacje współczesnego i pierwotnego ukształtowania terenu w aspekcie niwelacji i tworzenia nasypów powierzchniowych 1 - ukształtowanie powierzchni pierwotnej, 2 - ścięcie/podcięcie powierzchni terenu, 3 - współczesna równia niwelacyjna, 4 - ukształtowanie powierzchni pierwotnej/kopalnej po zdjęciu nasypów, 5 - grunt zniwelowany, 6 - grunt nasypowy. Powstanie: a - ściętej równi niwelacyjnej, b - ścięto-nasypowej równi niwelacyjnej, c - złożonej ścięto-nasypowej równi niwelacyjnej, d - nasypowej równi niwelacyjnej

Fig. 5. Relations of the contemporary and primary relief in terms of levelling and creating surface embankments

1 - primary relief, 2 - cutting/undercutting of surface, 3 - contemporary levelled plane, 4 - primary/fossil relief after removing the embankments, 5 levelled ground, 6 - embankment ground. Creating: $\mathrm{a}$ - cut plane, $\mathrm{b}$ - cut-and-fill plane, $\mathrm{c}$ - complex cut-and-fill plane, $\mathrm{d}$ - fill plane

Tereny dawnych wyrobisk eksploatacyjnych iłów, piasków i żwirów, obecnie najczęściej zasypane i zagospodarowane, znajdowały się niegdyś zarówno na wschód, jak i na zachód od Zespołu Staromiejskiego (Niewiarowski, Tomczak 1969). Pozostałością takiego wyrobiska (ryc. 1) jest cofnięta krawędź i obniżenie terasy rzecznej na północ od wspomnianego Portu Zimowego (Fedorowicz 1993, Tomczak 1999).

\section{Próba rekonstrukcji pierwotnego ukształtowania analizowanego terenu}

Jak już wspomniano, jednym z etapów rekonstrukcji pierwotnego ukształtowania obszaru Zespołu Staromiejskiego w Toruniu i jego bliskich przedmieść było oszacowanie miąższości nasypów powierzchniowych na badanym terenie w oparciu o analizę geostatystyczną danych geologicznych i archeologicznych. Wynik tej analizy i uzyskany obraz rozprzestrzenienia nasypów jest przybliżony, co jest efektem braku informacji geologicznej o części analizowanego terenu. Nasypy powierzchniowe o największej miąższości pokrywają się głównie z terenami XVIII- i XIX-wiecznych fortyfikacji miasta, tj. bastionów ziemnych i fos oraz, na wschód od granic Zespołu Staromiejskiego, z miejscami zasypanych dawnych wyrobisk eksploatacyjnych (ryc. 4). Nasypy te mają miąższość od 3 do $6 \mathrm{~m}$, maksymalnie, punktowo do ponad $10 \mathrm{~m}$. W obrębie Zespołu Staromiejskiego oraz przedmieść przylegających bezpośrednio do dawnych fortyfikacji miąższość nasypów wynosi od 1 do $3 \mathrm{~m}$. Na terenach położonych w dalszym otoczeniu średniowiecznego miasta miąższość ta jedynie lokalnie przekracza $1 \mathrm{~m}$. Obszar, gdzie nasypy praktycznie nie występują lub ich miąższość jest niewielka, to Kępa Bazarowa oraz część bliskich przedmieść ze znacznym udziałem zieleni miejskiej.

W oparciu o algebrę rastrową uzyskano rastrowy, cyfrowy model wysokościowy powierzchni rozpatrywanego terenu po zdjęciu nasypów. Z przyjętej procedury wynika, że pierwotna powierzchnia analizowanego terenu przed utworzeniem nasypów nie była niwelowana przez wyrównywanie i naruszanie gruntu, co jest niewątpliwym uproszczeniem (ryc. 5a, b, c). Stwierdzenie, czy kopalna powierzchnia była początkowo niwelowana (ścięta) i w jakim stopniu, nie jest możliwe na podstawie wierceń lub niewielkich powierzchniowo wykopów. Zachowanie ukształtowania pierwotnej powierzchni ma miejsce jedynie przy powstaniu tzw. nasypowej równi niwelacyjnej (ryc. 5d). W takich przypadkach poziom terenu jest wyższy niż pierwotnie, a sam nasyp powstaje ze względu na niewystarczającą stabilność podłoża lub niekorzystne stosunki wodne (Podgórski 1996). Analiza nasypów wykazała, że zapisem geologicznym takiej sytuacji może być zachowanie pod warstwą nasypów poziomu próchnicznego gleby lub osadów biogenicznych, związanych z pierwotnymi podmokłościami gruntu.

Wysokości cyfrowego modelu powierzchni rozpatrywanego terenu po zdjęciu nasypów zmodyfikowano w oprogramowaniu GIS. Usunięto formy antropogeniczne i dodano na podstawie analizy planów i map historycznych formy zniwelowane lub przekształcone. Uzyskany obraz 

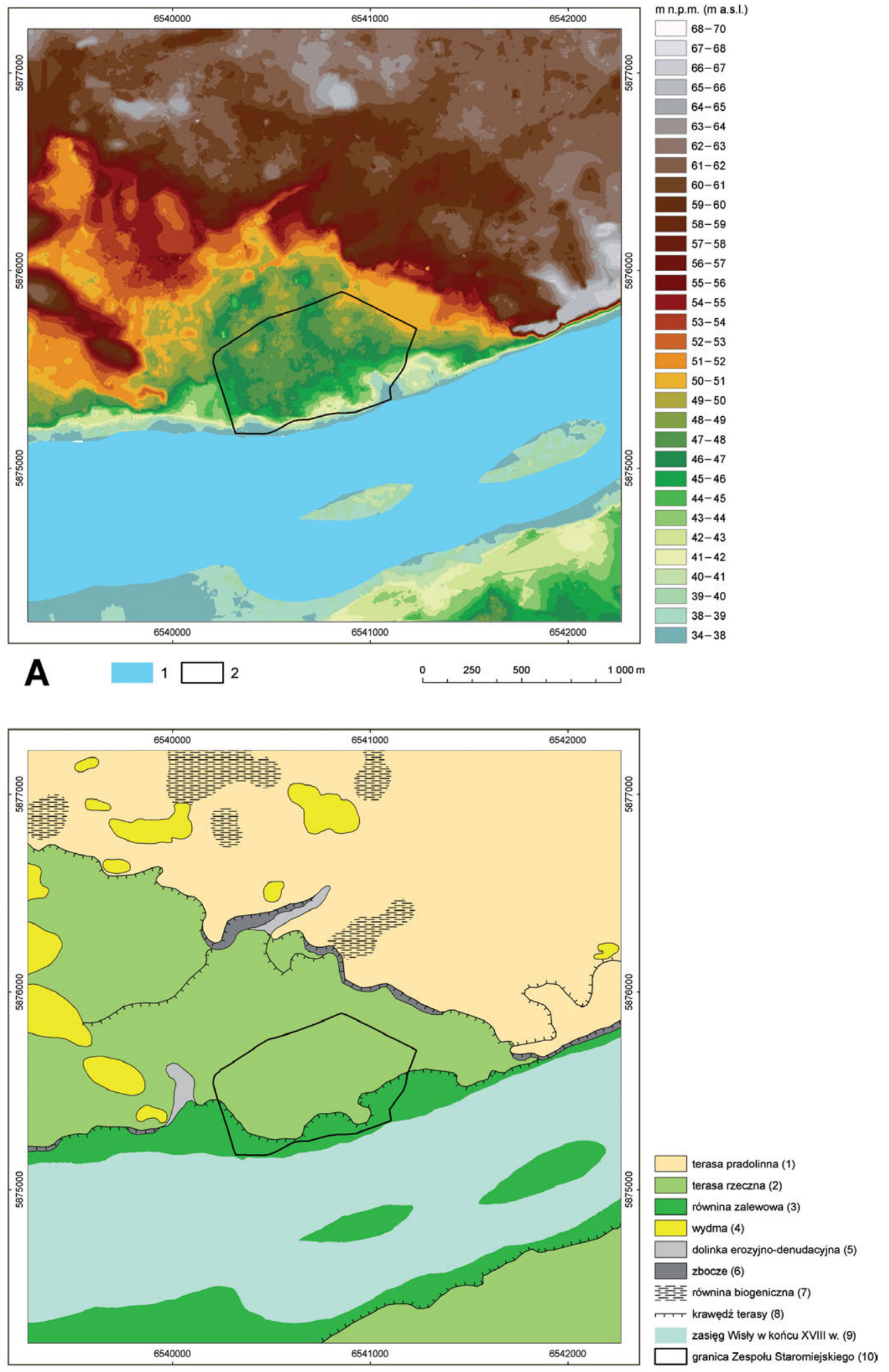

B $1000 \mathrm{~m}$

Ryc. 6. A - próba rekonstrukcji pierwotnego ukształtowania powierzchni analizowanego terenu

1 - Wisła na podstawie planu Douglasa z końca XVIII w. (vide ryc. 3A), 2 - granica Zespołu Staromiejskiego w Toruniu B - szkic geomorfologiczny zrekonstruowanego terenu

Fig. 6. A - attempt to reconstruct the primary relief of the analysed area

1 - Vistula river on the basis of the plan by Douglas from the late eighteenth century (vide Fig. 3A), 2 - boundary of the Old Town of Torun B - geomorphological sketch of the reconstructed area

1 - ice-marginal valley terrace, 2 - river terrace, 3 - floodplain, 4 - dune, 5 - erosion-denudational valley, 6 - slope, 7 - biogenic plain, 8 - escarpment of a terrace, 9 - extent of Vistula riverbed from the late eighteenth century, 10 - boundary of the Old Town of Torun 


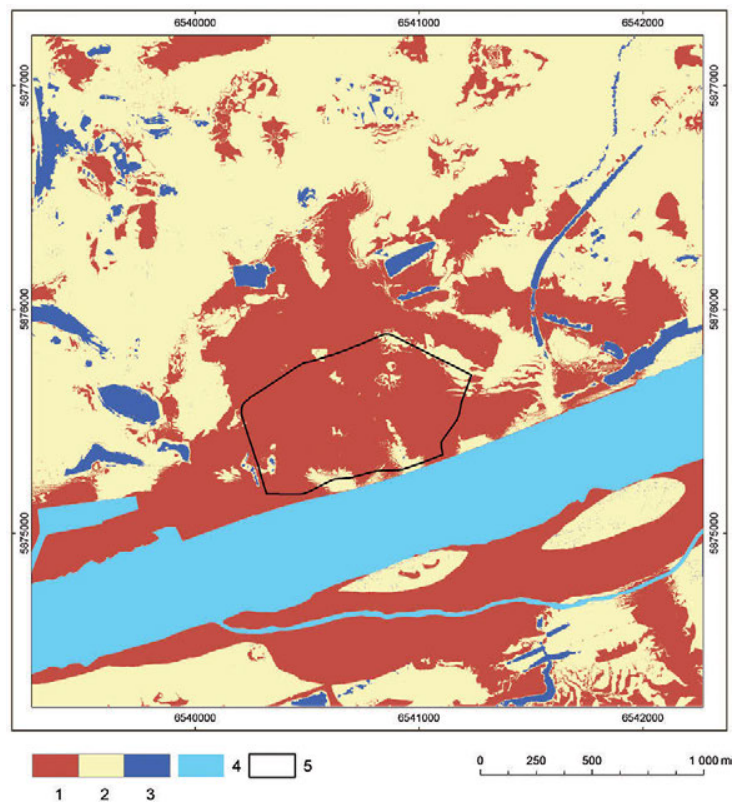

Ryc. 7. Szacunkowy bilans zmian rzeźby analizowanego terenu: 1 - dodatni bilans rzeźby, 2 - równoważny bilans rzeźby, 3 - ujemny bilans rzeźby, 4 - Wisła, 5 - granica Zespołu Staromiejskiego w Toruniu Fig. 7. Estimated balance of the relief changes in the analysed area: 1 - positive balance of the relief, 2 - sustainable balance of the relief, 3 - negative balance of the relief, 4 - Vistula river, 5 - boundary of the Old Town of Torun

ukształtowania terenu różni się od współczesnej morfologii obszaru Zespołu Staromiejskiego i jego bliskich przedmieść, choć jego zasadnicze rysy pozostały niezmienione (ryc. 6A). Na obraz ten wpływa istotnie znacznie większy od współczesnego zasięg Wisły. Jak już wspomniano, przypuszcza się, że od czasów lokacji miasta do końca XVIII w. zasięg ten był stabilny (Tomczak 1971). Na prezentowanej rycinie 6 zaczerpnięto go z rękopiśmiennego planu miasta z 1793 r. (ryc. 3A). O ile za wiarygodny możemy uznać zasięg koryta, o tyle hipotetyczne jest położenie i rozmiary Kępy Bazarowej i Zielonej. Wyraźnie obniżona została powierzchnia terasy rzecznej w granicach Zespołu Staromiejskiego oraz terenów przyległych do niego od północy. W efekcie bardziej wyraźna stała się krawędź terasy pradolinnej na północ i wschód od Zespołu Staromiejskiego (ryc. 6B). Na południowy wschód od Zespołu krawędź terasy rzecznej (nadzalewowej) została cofnięta na północ, wskazując jako naturalną przyczynę odsunięcie się Nowego Miasta od brzegów Wisły, zabezpieczające je przed powodzią. Zbocze terasy pradolinnej na północ od Zespołu Staromiejskiego oraz terasy rzecznej na zachód od niego rozcinają dolinki związane z pierwotnymi naturalnymi ciekami wodnymi (Fedorowicz 1993). Podobnie w obrębie Zespołu Staromiejskiego odzwierciedla się linijne obniżenie (ryc. 6A) będące być może śladem przebiegu naturalnego cieku przepływającego na wschód od wczesnohistorycznego grodu (Gąsiorowscy 1963 vide Fedorowicz 1993). W przebiegu krawędzi terasy rzecznej w południowej części Zespołu Staromiejskiego wyraźnie wyodrębnia się quasi-półwysep terasowy, na którym zbudowany został zamek krzyżacki. Jak już wspomniano, miejsce to było zasiedlane od końca epoki brązu (Chu- dziakowa 1963). Było ono preferowane prawdopodobnie ze względu na zabezpieczenie przed powodzią i walory obronne. Bardziej rozległe są istniejące do dzisiaj wzniesienia wydmowe w północnej i zachodniej części obszaru rekonstruowanej rzeźby, przypuszczalnie pierwotnie otoczone równinami eolicznych piasków pokrywowych, których zasięg praktycznie nie jest możliwy do otworzenia. Ponadto ukazane zostały wydmy współcześnie nieistniejące, głównie na Bydgoskim Przedmieściu na zachód od Zespołu Staromiejskiego. Obraz pierwotnej rzeźby uzupełniono równinami biogenicznymi, których zasięg wyznaczono na podstawie profili wierceń geologicznych, które wykazywały występowanie w płytkim podłożu osadów organogenicznych, głównie torfów, pod warstwą nasypów.

\section{Szacunkowy bilans zmian rzeźby}

Szacunkowego bilansu rzeźby dokonano poprzez odjęcie od cyfrowego modelu wysokościowego powierzchni współczesnej rozpatrywanego terenu, modelu wysokościowego powierzchni pierwotnej, zrekonstruowanej. Wydzielono obszary dodatniego bilansu rzeźby, gdzie pierwotna powierzchnia została nadbudowana antropogenicznie lub dobudowana $\mathrm{w}$ obrębie równiny zalewowej Wisły w efekcie naturalnych procesów fluwialnych wywołanych regulacją rzeki. Łącznie rejon ten zajmuje $34,3 \%$ analizowanego obszaru, $z$ czego około $1 / 3(10,3 \%)$ stanowi nadbudowana równina zalewowa. Na blisko połowie rozpatrywanego terenu $(47,0 \%)$ bilans rzeźby określono jako równoważny, tj. taki, gdzie nadbudowa lub obniżenie powierzchni nie przekroczyło $1 \mathrm{~m}$. Przyjęcie wartości $1 \mathrm{~m}$ wynika $\mathrm{z}$ zastosowanego na przedstawionych modelach wysokościowych cięcia poziomicowego (ryc. 1B, 6A). Ujemny bilans rzeźby wydzielono tam gdzie obniżenie pierwotnej powierzchni poprzez niwelację lub wykopy przekroczyło $1 \mathrm{~m}$. Tereny te zajmują 3,4\% analizowanej powierzchni. Pozostałe 15,3\% powierzchni zajmuje współczesne koryto Wisły. Wyraźna przewaga dodatniego bilansu rzeźby będącego efektem nadbudowy powierzchni terenu nad obszarami ujemnego bilansu wynika głównie $\mathrm{z}$ faktu niemożności wyodrębnienia terenów ściętych i ścięto-nasypowych równi niwelacyjnych (ryc. 5).

\section{Podsumowanie}

Przedstawiona rekonstrukcja pierwotnej rzeźby obszaru Zespołu Staromiejskiego w Toruniu i jego bliskich przedmieść ma przybliżony charakter. Zastosowana procedura, mimo wielu uproszczeń i ograniczeń, stanowi pierwszą próbę ilościowego odtworzenia pierwotnego ukształtowania analizowanego terenu. Jej wyniki wraz ze szczegółowym rozpoznaniem naturalnej powierzchniowej budowy geologicznej oraz trudnych do odtworzenia pierwotnych stosunków wodnych mogą stanowić podstawę do szczegółowego przedstawienia cech środowiska biotycznego, 
tj. pokrywy glebowej i naturalnej roślinności, analizowanego obszaru przed lokacją miasta. Ponadto może ona stanowić przesłankę do weryfikacji szczegółowych hipotez dotyczących uwarunkowań założenia i rozwoju przestrzennego Torunia.

\section{Podziękowania}

Pracę zrealizowano w ramach grantu MNiSW „Rozwój przestrzenny Torunia do początku XIX wieku (z uwzględnieniem środowiska naturalnego i osadnictwa przedlokacyjnego)" nr N N108223140.

\section{Literatura}

Biskup M. (red.), 1998. Toruń i miasta ziemi chełmińskiej na rysunkach Jerzego Fryderyka Steinera z pierwszej połowy XVIII wieku (tzw. Album Steinera). Towarzystwo Naukowe w Toruniu, Torun.

Chudziakowa J., 1963. Osadnictwo przedkrzyżackie na wzgórzu zamkowym w Toruniu w świetle ostatnich badań archeologicznych (1958-1961). Zapiski Historyczne 28(4): 590-600.

Fedorowicz J., 1993. Antropogeniczne przeobrażenia środowiska geograficznego na terenie miasta Torunia. Studia Societatis Scientiarum Torunensis, Geographia et Geologia 10(3).

Galon R., 1961. Morphology of the Noteć-Warta (or Torun-Eberswalde) ice marginal streamway. Pr. Geogr. Inst. Geogr. PAN 29.

Galon R., 1979. Formy powierzchni Ziemi. WSiP, Warszawa.

Jankowska M., 1993. Okoliczności powstania i sposób opracowania pruskiej mapy topograficznej z I połowy XIX wieku w skali 1:25 000. Roczniki Akademii Rolniczej w Poznaniu 240: 37-45.

Kondracki J., 1998. Geografia regionalna Polski. Wyd. Nauk. PWN, Warszawa.
Kwiatkowska E., 1973. Rozwój przestrzenny Torunia. Acta Universitatis Nicolai Copernici, Geografia 10: 187-209.

Molewski P., 1995. Przeobrażenia wybranych elementów środowiska naturalnego dzielnicy Torun-Mokre w czasach historycznych. W: Z. Babiński, J. Szupryczyński (red.), Człowiek a środowisko. 44 Zjazd Polskiego Towarzystwa Geograficznego, Toruń: 79-81.

Molewski P., 2011. Przeobrażenia rzeźby terenu i powierzchniowej budowy geologicznej dzielnicy Torunia - Mokre (Przedmieście Mokre) w czasach historycznych. Archaeologia Historica Polona 19: 189-202.

Niewiarowski W., Tomczak A., 1969. Morfologia i rozwój rzeźby obszaru miasta Torunia i jego okolic. Zeszyty Naukowe UMK, Geografia 6: 39-89.

Niewiarowski W., Tomczak A., 1973. Morfologia i rozwój rzeźby obszaru miasta Torunia i jego okolic. Acta Universitatis Nicolai Copernici, Geografia 10: 41-91.

Niewiarowski W., Weckwerth P., 2006. Geneza i rozwój rzeźby terenu. W: L. Andrzejewski, P. Weckwerth, S. Burak (red.), Toruń i jego okolice - monografia przyrodnicza. Toruń: 65-98.

Podgórski Z., 1996. Antropogeniczne zmiany rzeźby terenu województwa toruńskiego. Studia Societatis Scientiarum Torunensis, Geographia et Geologia 10(4).

Podgórski Z., 2005. Współczesne antropogeniczne zmiany rzeźby terenu na obszarze miasta Torunia. W: A. Kotarba, K. Krzemień, J. Święchowicz (red.), Współczesna ewolucja rzeźby Polski. VII Zjazd Geomorfologów Polskich, Kraków: 373-378.

Podgórki Z., Chechłowska K., 2011. Kierunki zmian krajobrazu warownego Torunia - ujęcie retrospektywne, diagnostyczne i prognostyczne. Koncepcje i problemy badawcze geografii. Wyd. Uczelniane Wyższej Szkoły Gospodarki, Bydgoszcz: 601-615.

Tomczak A., 1971. Kępa Bazarowa na Wiśle w Toruniu w świetle badań geomorfologicznych oraz archiwalnych materiałów kartograficznych. Studia Societatis Scientiarum Torunensis, Geographia et Geologia 7(6).

Tomczak A., 1999. Środowisko geograficzne Torunia i okolic. W: M. Biskup (red.), Historia Torunia. T. I. W czasach średniowiecza (do roku 1454). Toruń: 9-57. 